\title{
Renewed uplift of the Central Andes Forearc revealed by coastal evolution during the Quaternary
}

Vincent Regard $^{1,2,3}$, Marianne Saillard ${ }^{1,2,3}$, Joseph Martinod ${ }^{1,2,3}$, Laurence Audin ${ }^{1,2,3, *}$, Sébastien Carretier ${ }^{1,2,3}$, Kevin Pedoja ${ }^{4}$, Rodrigo Riquelme ${ }^{5}$, Paola Paredes ${ }^{1,2,3}$, Gérard Hérail $1^{1,2,3}$

1. Université de Toulouse ; UPS (OMP) ; LMTG ; 14 Av Edouard Belin, F-31400 Toulouse, France

2. IRD ; LMTG ; F-31400 Toulouse, France

3. CNRS ; LMTG ; F-31400 Toulouse, France

4. Laboratoire de Morphodynamique Continentale et Côtière, CNRS, Université de Caen, 14000 Caen, France

5. Departamento de Ciencias Geológicas, Universidad Católica del Norte, Avenida Angamos 0610, Antofagasta, Chile

* Now at LGCA, UMR-5025 CNRS, Maison des geosciences, 1381 rue de la piscine, 38041 Grenoble cedex, France

\section{Running title}

\author{
Quaternary Uplift of the Central Andes Forearc
}

\section{Abstract}

Most of the Pacific coast of the Central Andes, between $15^{\circ} \mathrm{S}$ and $30^{\circ} \mathrm{S}$, displays a wide (a couple of kilometres) planar feature, gently dipping oceanwards and backed by a cliff. This morphology, usually of marine orgin, is called rasa, and argues for a recent and spatially continuous uplift of the margin over the 1,500-km-long coastal region we describe. The cliff foot is found at a similar elevation $(\sim 110 \mathrm{~m}$ amsl) all over the studied area, with the exception of peninsulas such as the Mejillones Peninsula. The compilation of published chronological data and the extrapolation of re-appraised uplift rates provide evidence for a common cliff foot age of around $400 \mathrm{ka}$ (i.e., Marine Isotopic Stage MIS 11). This, together with other geological constraints, indicates a Quaternary renewal of uplift in the Central Andes forearc after a late Pliocene quiescence or subsidence.

Key words. Andes, Quaternary, Subduction, Rocky Coast, Geomorphology, Marine Terrace

\section{Introduction}

How and when the Andes reached their current elevation is highly debated. Studies have mainly focused on the Oligo-Miocene uplift (see the review by Ehlers and Poulsen, 2009). There is clear evidence that the Central Andes forearc (Figure 1) was 1,000 m lower than today during mid-Miocene, as demonstrated by the occurrence of mid-miocene marine strata at $\sim 1,000 \mathrm{~m}$ amsl (above mean sea level) (Huamán, 1985), and incision timing (e.g., Hoke et al., 2007; Schildgen et al., 2009; Schildgen et al., 2007; Thouret et al., 2007). Most of the uplift must have been achieved at the end of the Pliocene era, as indicated by a basalt flow we encountered at less than $250 \mathrm{~m}$ amsl near the bottom of the Ocoña valley, indicating that almost all the incision currently observed had already occurred; it has been dated some kilometres upstream, similarly near the valley bottom at 2.0 to 2.3 Ma (Schildgen et al., 2009; 
Thouret et al., 2007). Despite this, the coast presents many sequences of marine terraces and beach ridges, attesting to Quaternary uplift (e.g., Darwin, 1846; Domeyko, 1848; Gonzalez et al., 2003; Goy et al., 1992; Hartley and Jolley, 1995; Hsu et al., 1989; Machare and Ortlieb, 1992; Marquardt et al., 2004; Ortlieb et al., 1996a; Ortlieb et al., 1996b; Ota et al., 1995; Paskoff, 1977; Quezada et al., 2007; Saillard et al., 2009). Nevertheless, marine terrace sequences are not continuous (cf. Marquardt, 2005; Saillard, 2008).

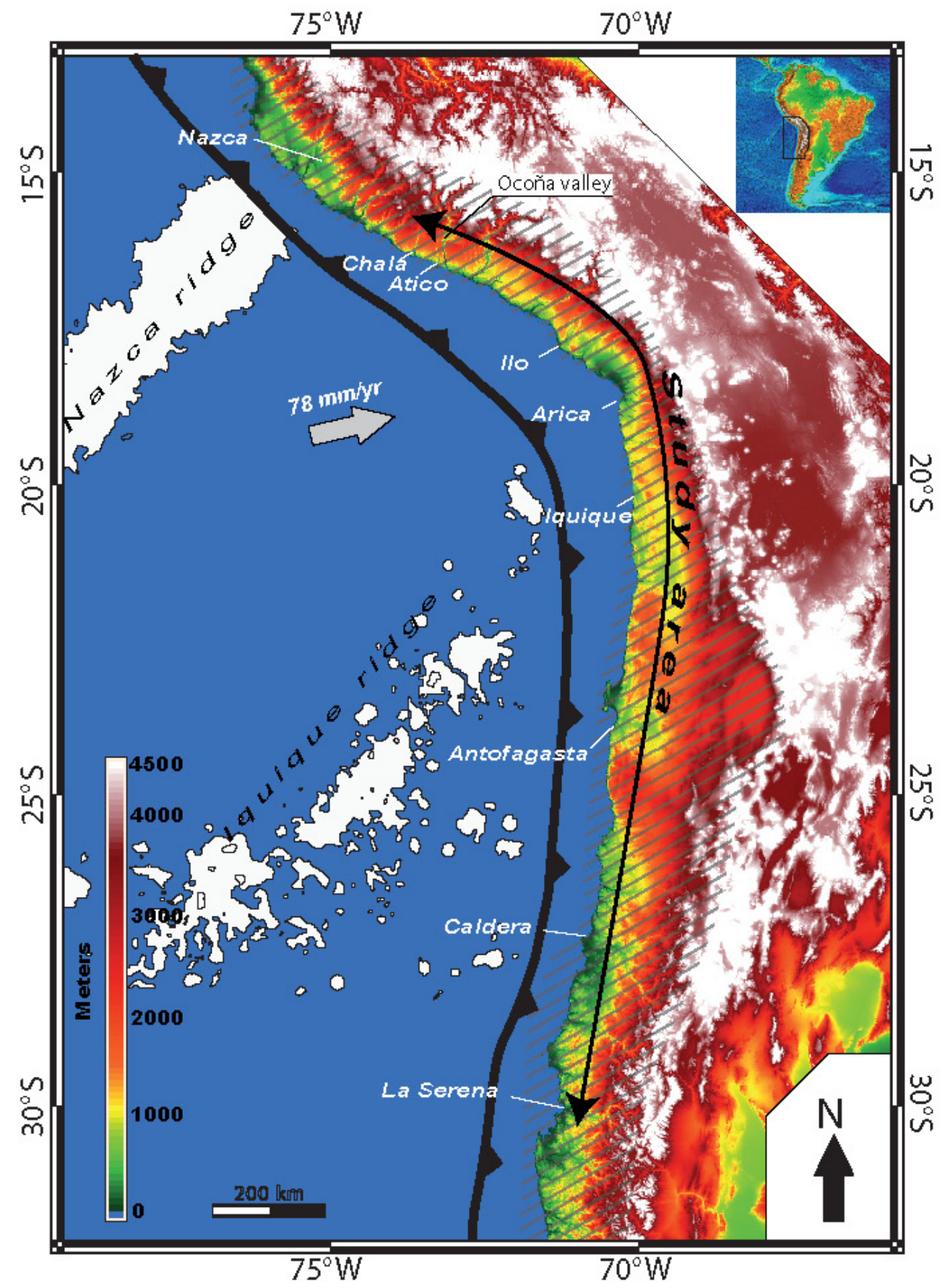

Figure 1. Central Andes topography (SRTM data) with the extent of the study area: the central Andes forearc is hatched. The trench is shown; convergence velocity does not vary much and the convergence vector is drawn for southern Peru, after Nuvel-1A model (DeMets et al., 1990). 

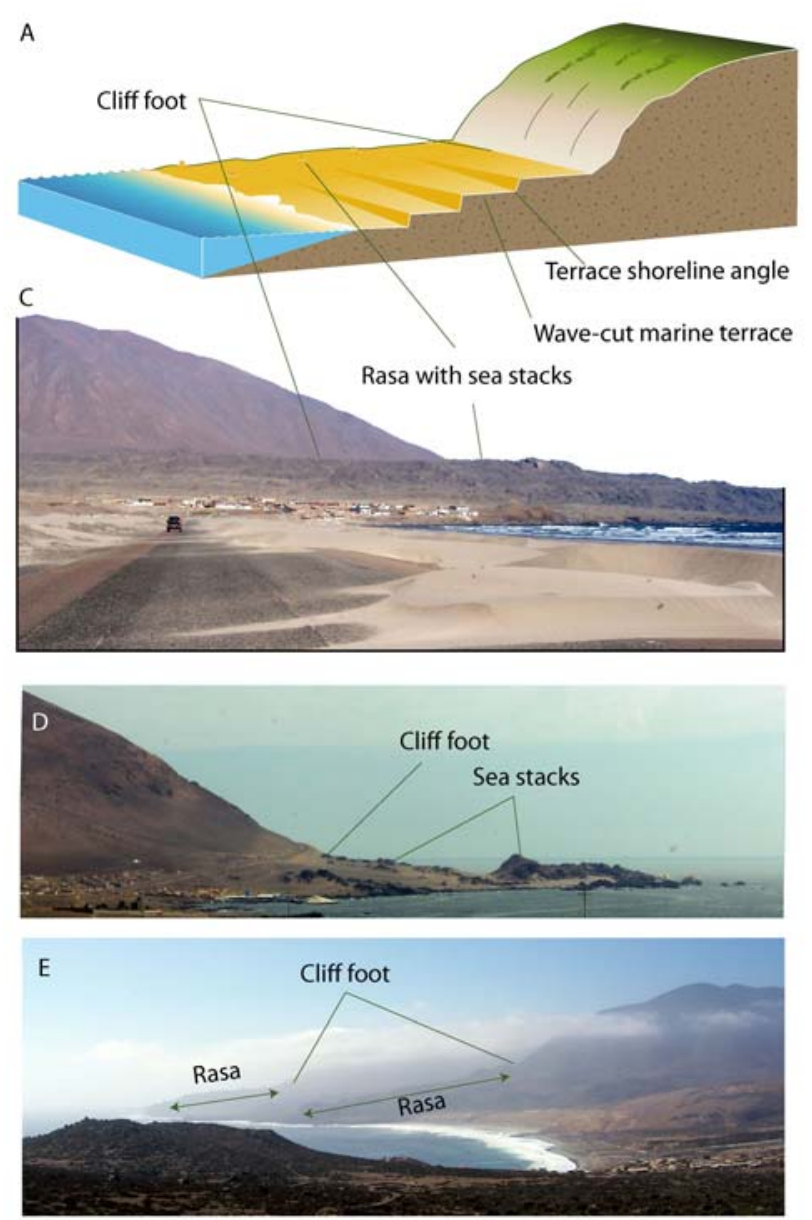
between the wave cut rasa and the terrace sequence.

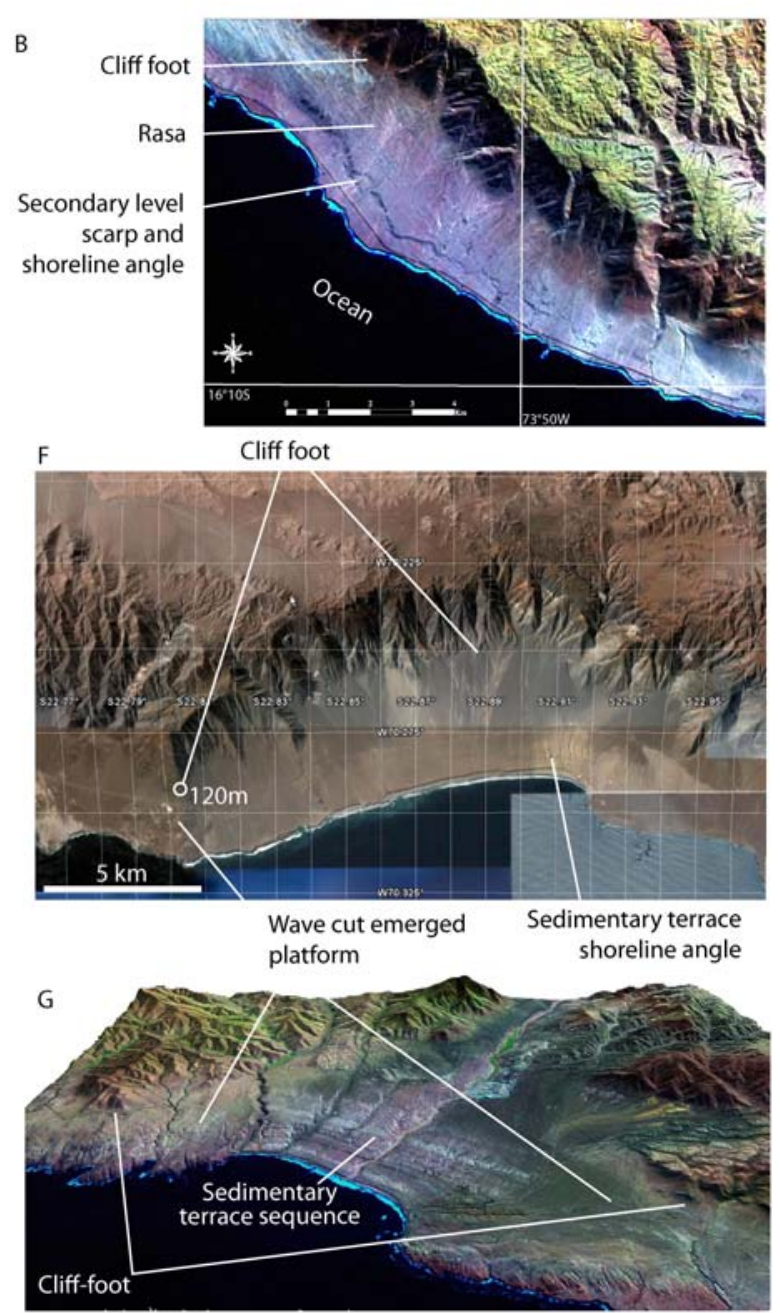

Figure 2. Schematic and field illustrations of rasa surfaces. A rasa is a gently dipping wave-cut surface, limited at its continent side by a cliff foot. A) General sketch of a rasa, which locally can be occupied by marine terraces. B) Landsat image of a rasa in southern Peru. C) The rasa and cliff at Tanaka (northern limit of this study, $15.75^{\circ} \mathrm{S}$, photo V. Regard); the cliff foot is at $\sim 300 \mathrm{~m}$ amsl. D) $\sim 50-\mathrm{m}$ rasa near Ite (Puerto Grau and Punta San Pablo, $\mathbf{1 8 . 0 0}^{\circ} \mathrm{S}$, photo L. Audin). E) Rasa near caleta de Hornos $\left(29.61^{\circ} \mathrm{S}\right)$; cliff foot is at 200-250 masl. F) Google Earth view of Hornitos (22.85응, showing the continuity between Hornitos' sedimentary terraces and a wave cut rasa; the cliff foot is measured far from the colluvial wedge at $120 \mathrm{~m}$ amsl; the summit of the cliff there is at $\sim 1,400 \mathrm{~m}$ amsl. G. Relief view of Chala Bay $\left(15.8^{\circ} \mathrm{S}\right)$ showing the transition

Another striking coastal feature of this region is defined by a morphology formed by a cliff bounding a gently sloping oceanward landform (Figure 2). This landform corresponds to a wave-cut landform with remnants of shore morphology such as seastacks or beach ridges (e.g., Hartley and Jolley, 1995; e.g., Marquardt et al., 2004; Ortlieb et al., 1996b; Paskoff, 1970; Paskoff, 1977; Paskoff, 1978; Radtke, 1987; Saillard, 2008). It differs from a marine terrace as its slope and relief are too high to constitute a simple terrace. However, it is sometimes laterally connected to marine terrace sequences like in Chala (Peru, Goy et al., 1992; Saillard, 2008)(Figure 2A). Similar features have been described along the northern Spanish coast where it could be 1-2 Ma-old (Alvarez-Marron et al., 2008). There, the term "rasa" was used to define a planation surface due to repeated highstands superimposed on an 
uplifting coast (Cueto y Rui Diaz, 1930; Hernandez-Pacheco, 1950). After its formation, a rasa can be degraded by depositional (e.g. fan deposition or reoccupation) or erosional (e.g. cliff degredation) processes, resulting in a less marked cliff-foot. Hereafter, we follow Paskoff (1970) and refer to the coastal landform that we find relatively continuously from Nazca, Peru to Valparaiso, Chile (Figure 1) as a rasa (Figure 2).

We present a compilation of the Southern Peru-Northern Chile rasa cliff-foot elevation. In the literature, cliff-foot is often named as a shoreline angle or inner edge. In the following, 'cliff-foot' refers to the foot of the main rasa cliff and 'shoreline angle' to the foot of the secondary cliffs of the marine terraces (cf. Figure 2A). As in Northern Peru and Ecuador, we consider that the rasa, and therefore its cliff-foot elevation, corresponds to repeated sea level highstands superimposed on a "stable" or slowly uplifting rocky coast. In other words, only a succession of different highstands can produce such a wide morphology. We discuss its elevation distribution all over the study area in terms of uplift. Then, we review the literature concerning Quaternary palaeoshore dating (and correlation to Marine Isotopic Stages (MIS)) and attempt to extrapolate it to date this shore platform formation and emersion. We finally discuss the timing of rasa formation and forearc uplift along the coast of the Central Andes.

\section{Study area and geological setting}

The study area extends for $1,800 \mathrm{~km}$ along the central Andean coast, from Tanaka to the north (southern Peru, $74.4^{\circ} \mathrm{W}, 15.7^{\circ} \mathrm{S}$ ) to the La Serena area to the south (northern Chile, $71.3^{\circ} \mathrm{W}, 30^{\circ} \mathrm{S}$ ). We chose this study area because, as shown in this work, this segment of the Andean coast is currently uplifting, and displays many uplifted geomorphologic features. Further north, between Tanaka and Pisco, coastal uplift is accelerated by subduction of the southward-migrating Nazca Ridge (Espurt et al., 2007; Hampel, 2002; Machare and Ortlieb, 1992; Regard et al., 2009; Wipf et al., 2008). In turn, north of Pisco, in the Lima area, the coast segment is currently subsiding (le Roux et al., 2000), possibly related to the transient response following the passage of oceanic ridge subduction.

Southward of La Serena, the morphological signal is harder to interpret, probably as a result of the combined effects of greater complexity, and a greater dissection by the wetter climate. The morphological complexity of the La Serena area could be interpreted as local uplift induced by the nearby subducting Juan Fernandez ridge and its associated flat subduction segment (Le Roux et al., 2005; Yañez et al., 2002). But, in contrast to the Nazca ridge, whose meeting point with the coast is migrating southwards (Hampel, 2002), the Juan Fernandez ridge has been subducting beneath the same coastal position since $\sim 10 \mathrm{Ma}$ (Yañez et al., 2001), long before the formation of Quaternary uplifted shorelines. This segment of Andean coast is usually marked by the Coastal Cordillera; it has relief in the order of $\sim 1,000$ $\mathrm{m}$, except in the Arica bend between Ilo and Arica where the coast dips gently oceanwards. The coastal relief is particularly well expressed in northern Chile between Arica and Antofagasta, where the coastal geomorphology is described as an ocean-facing cliff (i.e., Gonzalez et al., 2003; Ortlieb et al., 1995). This relatively simple cliff-face coastal morphology is interrupted by peninsulas such as Ilo, Mejillones or the area south of Caldera, where some of the best preserved coastal sequences are preserved.

Marine terraces and rasas developed over the coastal batholith, forming the Coastal Cordillera all along the study area (Gansser, 1973). Flat surfaces and depressions are located to the east, between the Coastal and Main Cordilleras. They are often filled by Miocene or older clastic sediments (for example the Moquegua Group in southern Peru (Huamán, 1985), or El Diablo Formation in northern Chile (Tobar et al., 1968)). The marine origin of rasas is attested by fossils found on them, the remains of sea stacks, the continuity with marine terrace deposits and the ages they yield close to that of the neighbouring marine terraces (Hartley and 


\subsection{Cliff-foot}

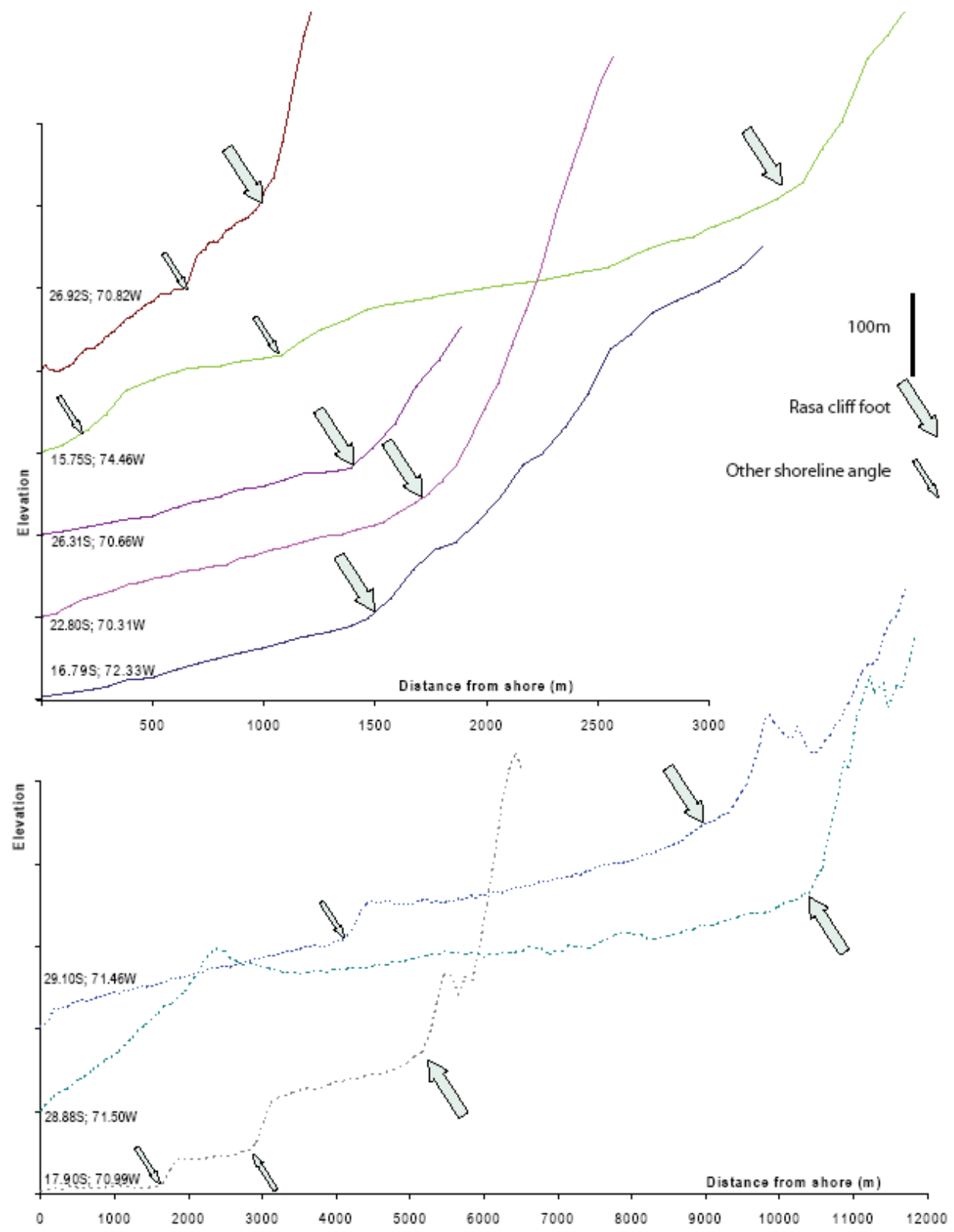

Figure 3. Example of profiles normal to the shore (the coordinates of the profiles at the coast are indicated). All the profiles have the same vertical scale $(100 \mathrm{~m}$ between tickmarks) but the horizontal scale differs between top profiles (continuous line) and bottom ones (discontinuous line). Greater and smaller arrows indicate, respectively, the rasa cliff foot and other shoreline angles.

Topographic analyses are based on Shuttle Radar Topography Mission (SRTM) digital elevation models (DEMs) with a spatial resolution of 3 arc seconds $(\sim 90 \mathrm{~m})$ and a vertical accuracy of $\sim 10 \mathrm{~m}$ (Farr et al., 2007). We generated cross-sections normal to the shore where the cliff-foot is clearly visible (see examples in Figure 3), and basement rock outcrops, attested by the rasa surface shape and the presence of sea-stacks (cf. Figures 2B, 2C and 2D): the sediment cover is thus negligible. We recorded cliff-foot elevations for each cross-section along the coast (Figure 4). 


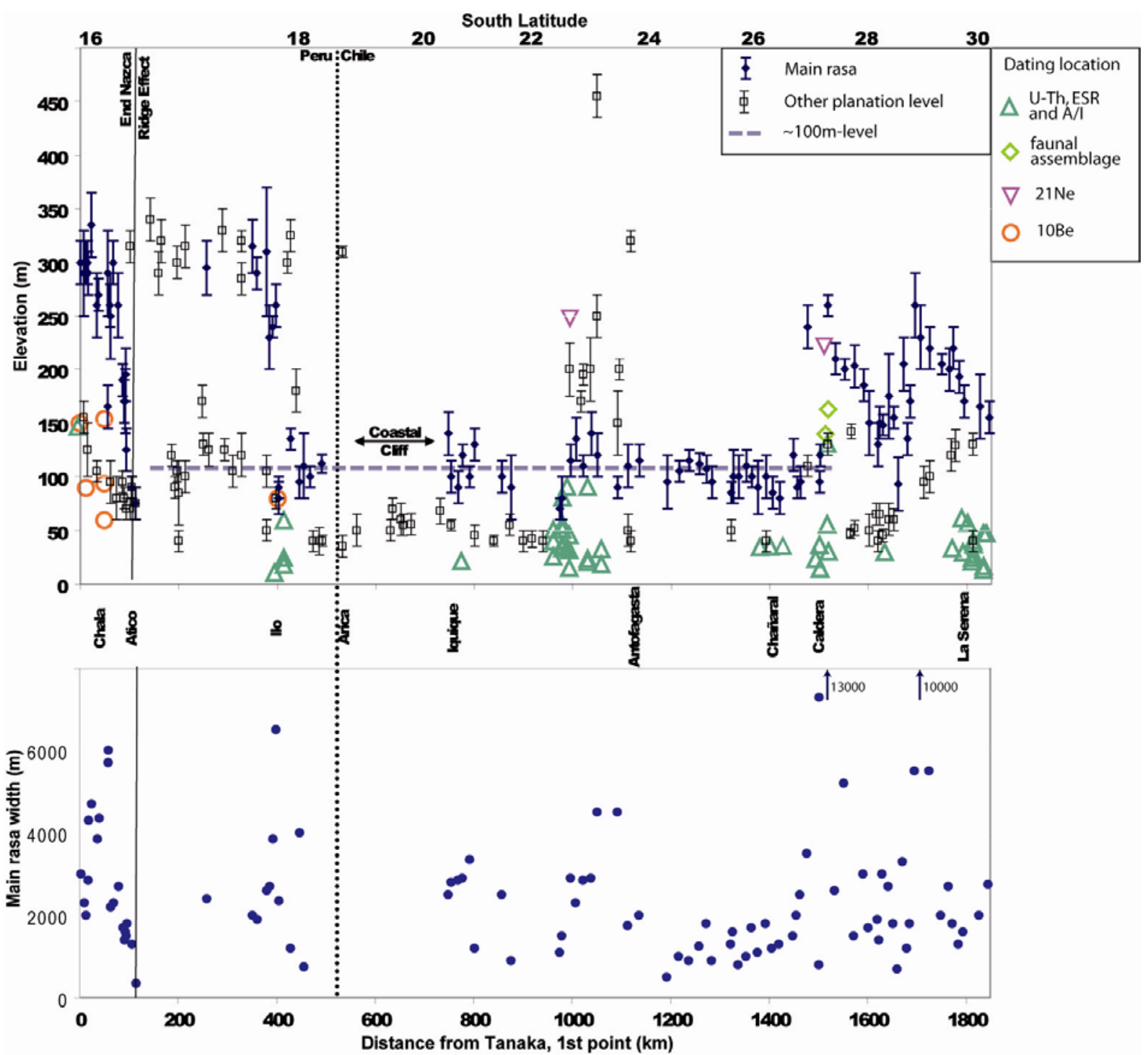

145

146

147

148

149

150

151

152

153

154

155

156

157

158

159

160

161

162

163

Figure 4. Top: cliff foot elevation of the main planar levels vs. distance from Tanaka. The main rasa is indicated by black diamonds whereas other levels are indicated by white squares. A level at $\sim \mathbf{1 0 0} \mathbf{m}$ amsl appears clearly between Atico and Caldera (kilometres 100 to 1500). Before and after, the surface elevation trend is less clear. An upper level is found in southern Peru at $\sim 300 \mathrm{~m}$ amsl, and a lower one at $\sim 50 \mathrm{~m}$ amsl is found discontinuously all over the area. The $\sim 110-\mathrm{m}$ main level and lower level are progressively uplifted from kilometre 100 (respective elevations of $110 \mathrm{~m}$ and $70 \mathrm{~m}$ amsl) to kilometre 0 (respective elevations of $300 \mathrm{~m}$ and $150 \mathrm{~m}$ amsl), probably due to the subduction of the Nazca Ridge underneath. White triangles, diamonds and circles indicate dating locations and the technique used (see caption). Bottom: main rasa width (same points as top graph).

This exercise revealed one to three planar coastal features in the study area (Figure 4). Among these surfaces, the main one has a width of between 1 and $3 \mathrm{~km}$ on average, and in some places reaches $10 \mathrm{~km}$ (Figure 4). It lies at $110 \pm 20 \mathrm{~m}$ amsl between Atico and Caldera. This feature corresponds to a rasa, and is almost continuous in southernmost Peru and northern Chile, from Iquique to Caldera. In southern Peru, to the north of Atico this level is a well developed rasa. Its elevation progressively becomes higher and reaches $\sim 300 \mathrm{~m}$ amsl in the Chala area. Between Atico and Ilo, this level is discontinuous and less clear (Figure 4). 
In southern Peru, a level higher than the $\sim 110 \mathrm{~m}$ amsl one is found in some places between Tanaka and Ilo; it is not well preserved and stands mainly at $\sim 300 \mathrm{~m}$ amsl. In Chile, planation levels higher than the $\sim 110 \mathrm{~m}$ one are only present near (and within) the Mejillones Peninsula and southward from Caldera (Figure 4).

A lower surface, usually located between 40 and $60 \mathrm{~m}$ amsl (cf. Marquardt, 2005), is present discontinuously all over the area, but without major variations in its elevation except in the northernmost part, north of Atico. There, its elevation increases northward, similarly to the $\sim 110-\mathrm{m}$ main level, and reaches $150 \mathrm{~m}$ amsl at the northern end of the study area (Figure 4). This level is sometimes cut into the main rasa (see Figure 2C for example).

In the southernmost $300 \mathrm{~km}$ of the study area, the extensive rasa displays a wide range of elevations (100-250 m) with no clear trends. We find this wide range to be typical in uncommonly large rasas (i.e., greater than $4 \mathrm{~km}$ wide, Figure 3), such as around Mejillones or Ilo, areas whose Quaternary uplift is known to be complex (Marquardt et al., 2004; Ortlieb et al., 1996a).

\subsection{Chronological Constraints}

A significant number of studies have been conducted to date the Quaternary sequence of shorelines (and particularly the marine terrace deposits). Dating was performed using amino acids racemisation, electron spin resonance (ESR), U-Th, cosmogenic nuclide dating, or the faunal content of the terrace (for shorelines related to MIS 11) (see references in Table 1). Chrono-stratigraphic interpretations for each site (detail of individual dates are described in additional material) allow us to determine an uplift rate based on the paleoshorelines. Assuming that this uplift rate is representative of uplift since the abandonment of the rasa surface final abandonment, we used this uplift rate to extrapolate the age of the upper rasa cliff foot. We present the methodology and dates used and then discuss the validity of our extrapolation.

\subsubsection{Methodology and dates used}

The age of the rasa could be evaluated using the following equation, assuming a constant uplift rate over geologic times: $A g e_{E S P}=\frac{z_{c f} A g e_{\text {Terrace }}}{z_{t}-s l}$ where $z_{c f}$ and $z_{t}$ are the elevations of the cliff foot and the terrace shoreline angle respectively, on which the extrapolation is made; and $s l$ is the highstand sea level. This hypothesis will be discussed below, because it has been shown previously to be erroneous in the case of Altos de Talinay where the uplift rate varied in time (Saillard et al., 2009). This exercise gives results for 16 sites ( 2 of them can each be divided into sub-sites) for the age of the $\sim 110 \mathrm{~m}$ amsl and upper levels (Figure 5 and Table 1 ). The maximum distance between two evaluations is $\sim 500 \mathrm{~km}$ (Figure 4 ). The dating results found in the literature are compiled for each terrace of each site (details are in Table in the additional material).

It is now widely accepted that terrace inner edges correspond to sea level highstands, which are correlated to odd Marine Isotopic Stages (i.e. MIS 5, 7, 9 in Table 1)(e.g., Bradley and Griggs, 1976; Keller and Pinter, 2002; Lajoie, 1986). Highstands are generally complex with second order variations referred to as sub-stages (for example $5 \mathrm{a}, 5 \mathrm{~b}$, etc.). Each substage represents a long enough still-stand in sea level that can result in significant morphogenesis, but generally interglacial maxima (or peaks) corresponding to the highest highstands (e.g. MIS 5e) are best expressed in the landscape (Bull, 1985; El-Asmar, 1997; Lajoie, 1986; Muhs, 1983; Pedoja et al., 2006b; Pirazzoli et al., 1993). Thus authors typically relate terrace formation to one of the sea level highstands (column 'MIS' in Table 1), which generally offer much more precise timing constraints than the reported dating results. In our 
study we similarly preferred a correlation of shoreline angle to the peaks of past interglacials (in Obispito for example, Table 1 and additional material). These highstands (MIS or substages) are relatively well known, at least in terms of timing, if not in terms of elevation of past sea levels relative to the modern one (e.g., Siddall et al., 2006) (see Table 1). Moreover, assigning the dates to an MIS allows taking into account the global sea level (sl) at this time: this is reported in Table 1 and used in the aforementioned equation to calculate the age of the rasa at the cliff foot. The associated error indicated in Table 1 is a result of propagation of the errors on Age $\mathrm{MIS}_{\mathrm{S}}$ the MIS (or substage) age, sl, the MIS sea level, $z_{c f}$, and $z_{t}$. Its complete expression is:

$$
\frac{\Delta\left(\text { Age }_{E S P}\right)}{\text { Age }_{E S P}}=\sqrt{\left(\frac{\Delta\left(z_{c f}\right)}{z_{c f}}\right)^{2}+\left(\frac{\Delta\left(A g e_{M I S}\right)}{A g e_{M I S}}\right)^{2}+\left(\frac{\Delta\left(z_{t}\right)+\Delta(s l)}{z_{t}-s l}\right)^{2}} \text { where } \Delta(\mathrm{x}) \text { is the error on } \mathrm{x} \text {. }
$$

Rarely, rasa deposits or the erosion surface itself have been dated in a site close to the cliff foot (Table 1: Saillard et al. 2009 for Ilo and Altos de Talinay; Leonard et al. 1994, Marquardt et al. 2004, and Quezada et al. 2007 at Caldera/Bahia Inglesa). In these cases, there is no need to extrapolate the age; consequently, we derived these ages through direct dating and we regard them as particularly reliable (highlighted in Figure 5 and Table 1).

\subsubsection{Results: extrapolated cliff foot ages}

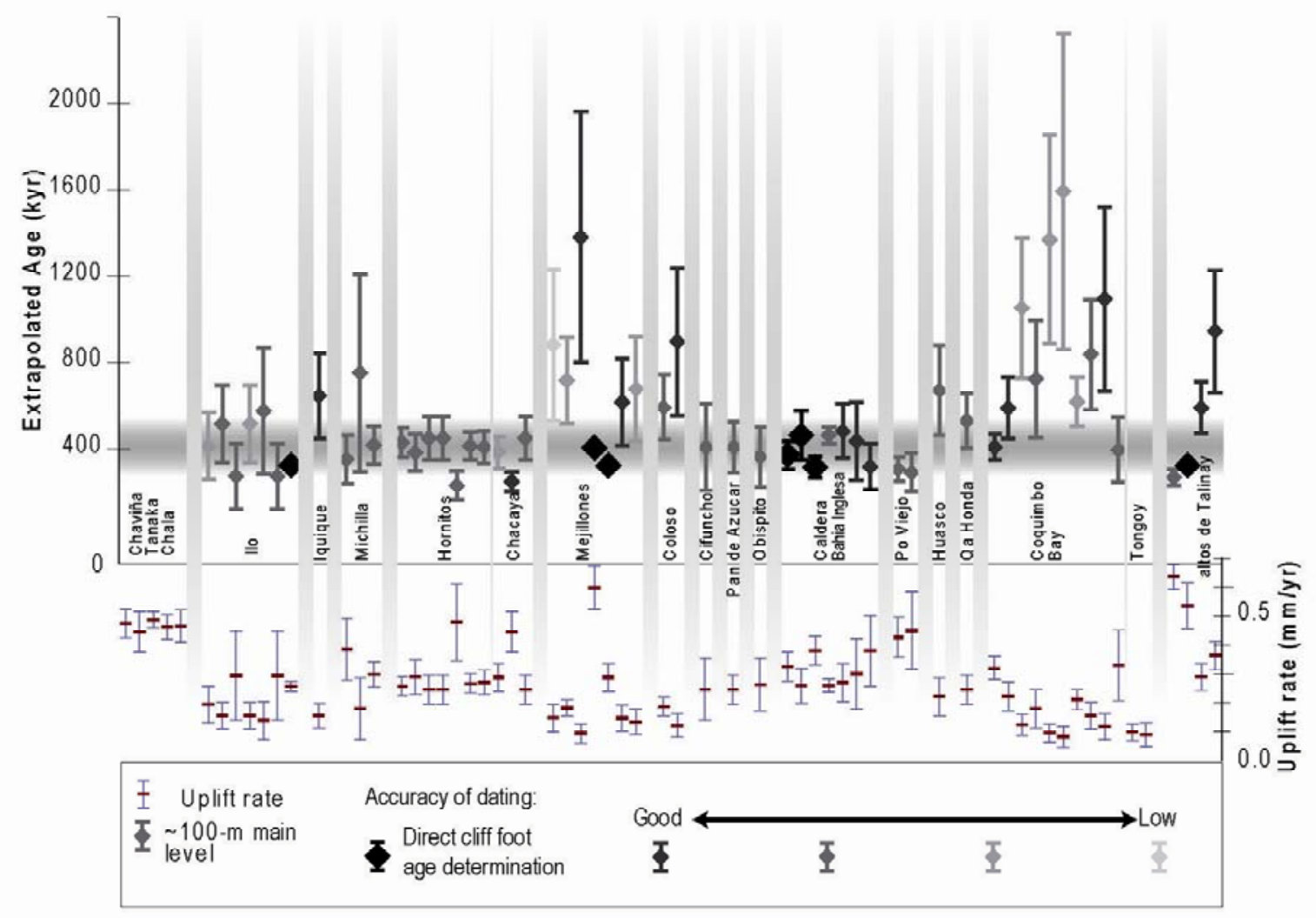

Figure 5a. Extrapolation of terrace ages to cliff foot for the main, $\sim 100 \mathrm{~m}$ amsl level. Each datum comes from a different study (see Table 1). The calculated uplift rates are reported at the bottom. For each site (from north to south), the different evaluations are shown (see Table 1). Extrapolations that seem more reliable than others are highlighted in larger and bolder symbols (see text for why they are more reliable). Most of the extrapolated ages fall in the range, $400 \pm 100 \mathrm{ka}$. 


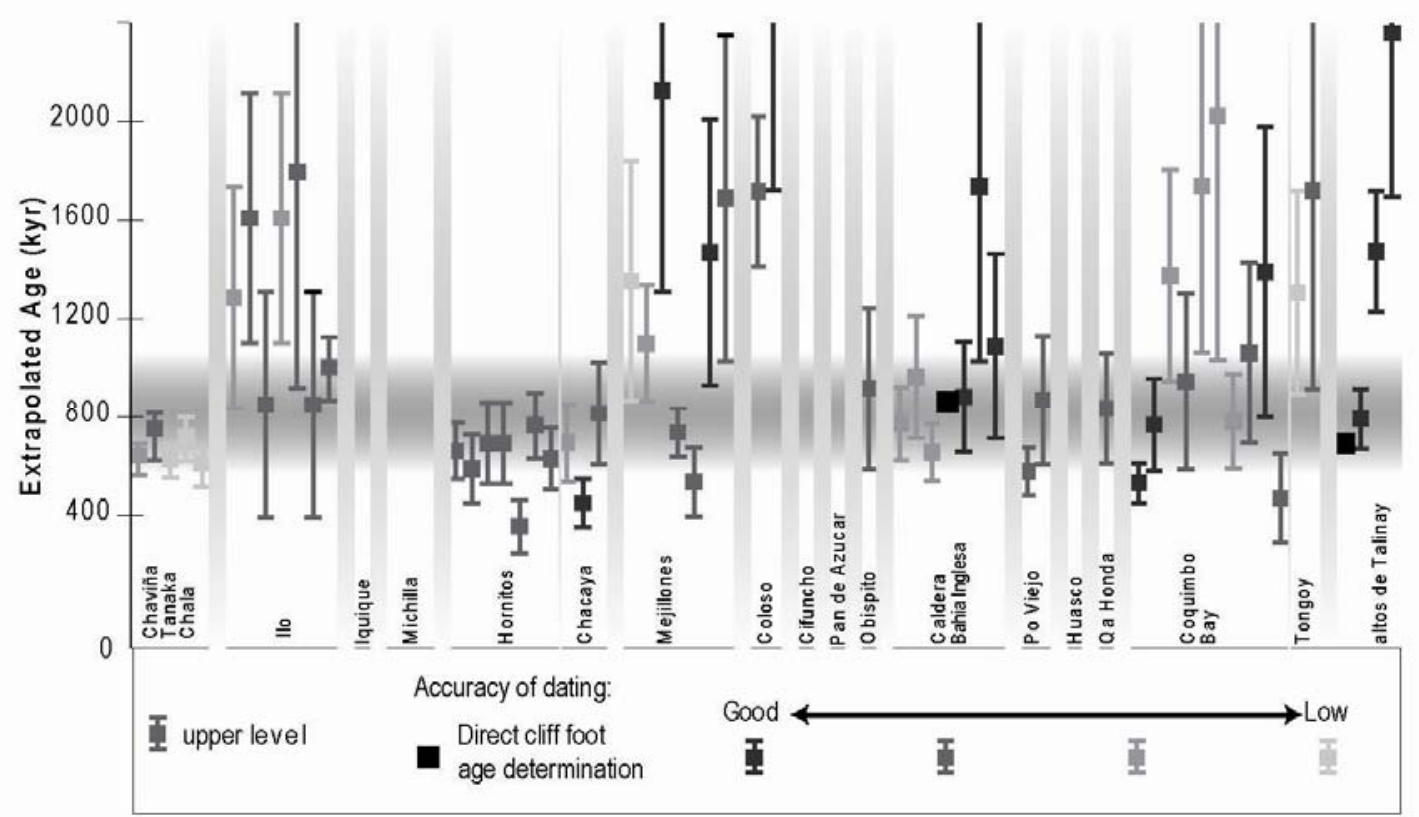

Figure 5b. Same as Figure 5a, for the upper level. Most of the extrapolated ages fall in the range $800 \pm 200 \mathrm{ka}$, but they are more scattered than for the $\sim 110-\mathrm{m}$ main level.

The $\sim 110 \mathrm{~m}$ level age has been evaluated with our technique to $\sim 400 \pm 100 \mathrm{ka}$ (Figure 5a

\section{Discussion}

This work aims at defining Quaternary rasa development in the study area, before placing this story in the framework of Andean Cenozoic growth and rise. The study area displays some rasas between $\sim 16^{\circ} \mathrm{S}$ and $30^{\circ} \mathrm{S}$. These probably represent a period with steady sea level highstands, reaching quite the same level (Siddall et al., 2010), long enough to cut a high and Table 1). A couple of sites display a different age, but they are located around the Mejillones Peninsula (Abtao and north Mejillones) and the Coquimbo-Tongoy Bay, areas already known for their tectonic complexity (Marquardt, 2005; Ortlieb et al., 1996b; Paskoff et al., 1995). Some sites yield different uplift rates depending on the terrace used, such as in Altos de Talinay and possibly at Abtao in the Mejillones Peninsula. In these two cases, we used the dated terrace with elevation closest to that of the cliff foot as being most representative (cf. Figure 5a and Table 1). Other sites display relatively similar uplift rates, regardless of the level of the dated terrace (sites Caldera/Bahia Inglesa, Chacaya/Hornitos, Ilo and possibly Abtao and the Coquimbo Bay, Figure 5a and Table 1). These sites give evidence for a constant (or slightly changing) uplift rate, different from the highly variable one calculated for the Altos de Talinay by Saillard et al. (2009).

For the 150 to 450-m upper level, in a similar way, we extrapolated uplift rates derived from dated terraces found at lower levels, or chose the closest terrace from which to derive uplift rates if there was evidence for variability. Despite a greater uncertainty, the data highlight a possible common cliff foot age for the different sites at around $800 \pm 200 \mathrm{ka}$ (cf. Table 1 and Figure $5 b$ ). We believe this age estimate is reasonable since this result is close to direct dating of the rasa at the cliff foot (Figure 5b) in Altos de Talinay (678 \pm 51 10Be kyr, Saillard et al., 2009) and in Caldera (860 110 21Ne kyr, Quezada et al., 2007). coastal cliff. This period was followed by uplift during which repeated highstands allowed for extensive wave-cut platform (rasa) development or terrace deposition probably in function of the palaeogeography and tectonics, as illustrated by the peninsulas (Marquardt, 2005; 
Marquardt et al., 2004; Saillard, 2008; Saillard et al., 2009). This platform emerged and is preserved through fossilization of the abandoned cliff foot (Figure 6). In this scenario, the rasas in southern Peru and northern Chile can be regarded as evidence for a stage without uplift (platform underwater development) preceding an uplift period lasting until modern times. The coast shows a record of Quaternary uplift along more than $1,500 \mathrm{~km}$, as indicated by the $\sim 110-\mathrm{m}$ main level. The lowermost level $(\sim 50 \mathrm{~m})$ is more continuous, in particular in areas not known for displaying emerged coastal features like northernmost Chile. This uplift, after a period of relative stability or subsidence, started at $400 \pm 100 \mathrm{ka}$, based on our extrapolated age for the major rasa surface identified at $\sim 110 \mathrm{~m}$ amsl. The age probably corresponds to MIS 9 and/or 11 (321 or $404 \mathrm{ka}$, respectively, the latter value being considered more representative). A higher shore platform, found only in Peru and in the Chilean peninsulas, could have an age extrapolated to around 800-1000 ka. This stage has possibly left remnants, not only in southern Peru and on the peninsulas, but also in northern Peru and southern Ecuador. Indeed, extensive marine landforms, locally called tablazos, are present there at $\sim 300 \mathrm{~m}$ amsl with an age similarly estimated to be older than 700 ka by Pedoja et al. (2006a; 2006b).

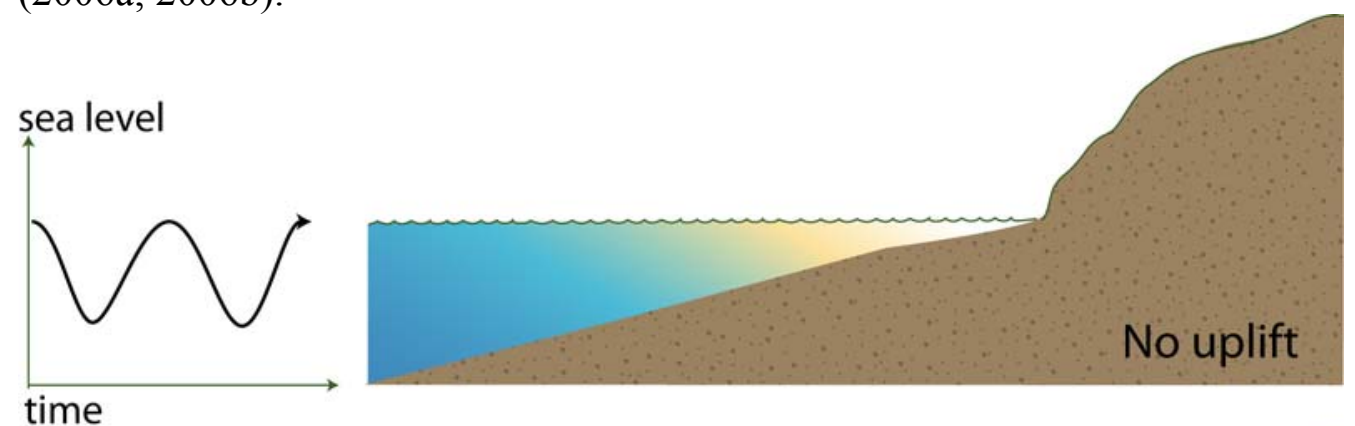

time

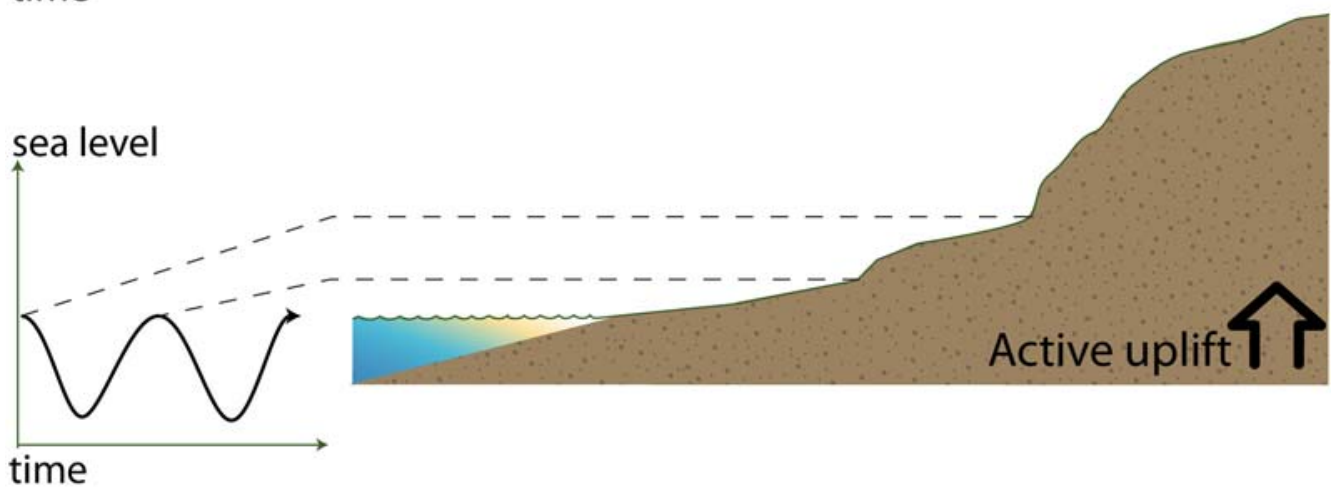

Figure 6. Rasa development in relation to uplift. Top: initial stage resulting from a long period without uplift and shore platform underwater development. Bottom: emergence because of uplift. Glacio-eustatic cycles could be recorded by small features within the rasa.

Indeed, our data emphasizes the particular setting of the peninsulas. The peninsula areas generally have a well-developed rasa of "standard" age (ca $400 \mathrm{ka}$ ), but they also have higher well-developed surfaces (possibly clustered around $800 \mathrm{ka}$ ). These observations correlate with other information regarding the MIS 11 sea level highstand. Observations from Siddall et al. (2006) indicate global, long-standing (at least $30 \mathrm{ka}$ ) high sea-levels during MIS 11. This could have driven extensive platform development. The question of why the peninsulas behave differently from the main onshore forearc remains open. They are all affected by Quaternary normal faults, whether they are shore-perpendicular as in Ilo (Audin et al., 2008), shore-parallel as in Mejillones (Delouis et al., 1998; Hartley and Jolley, 1995) or Tongoy (Ota et al., 1995), or slightly oblique to the coastline as in Caldera (Marquardt et al., 2004). On one hand, this observation supports the scenario proposed by Delouis et al. (1998), that the 
peninsulas are active horsts which will subside when subduction erosion counterbalances the coast, indicating that either the model is incorrect or that tectonic erosion does not yet balance uplift.

A similar renewal of uplift was deduced by Clift and Hartley (2007) on the basis of offshore sedimentation. They suggested that the renewal took place after the upper MiocenePliocene subsidence at around $2 \mathrm{Ma}$, with low accuracy on their timing constraints. In northern Chile, the data compilation by Le Roux et al. (2005) indicates that except when the Juan Fernandez Ridge passed into subduction, the Coquimbo area underwent slight subsidence during late Miocene and Pliocene. The Andean forearc uplift was quantified in Northern Chile to $\sim 0.1 \mathrm{~mm} / \mathrm{yr}$ in the precordillera between 26 and $8 \mathrm{Ma}$, dropping to $\sim 0.02$ $\mathrm{mm} / \mathrm{yr}$ on average for the last $8 \mathrm{Ma}$ (Farías et al., 2005). More accurate dating indicates uplift and canyon incision between $\sim 10$ and $\sim 5 \mathrm{Ma}$ (Hoke et al., 2007; Schildgen et al., 2009; Schildgen et al., 2007), with no more than $250 \mathrm{~m}$ postdating the 2.0 to 2.3 Ma-old Ocoña basalt in southern Peru (Schildgen et al., 2009; Thouret et al., 2007). Similarly, near Arica, the 2.55-2.7 Ma Lauca tuff is present at $\sim 60 \mathrm{~m}$ amsl in the Lluta river, and between the Lluta river and the Arica airport (Garcia et al., 2004; Wörner et al., 2000), whereas Quaternary marine sediments crop out at a higher elevation, indicating Pliocene subsidence followed by uplift. Our observations are more precise, both in timing and in the spatial extent of deformation. Our estimated uplift rate is quite rapid $(0.25-0.3 \mathrm{~mm} / \mathrm{yr})$, and cannot reasonably be extrapolated in the Pliocene (1,000 $\mathrm{m}$ of uplift can be produced in less than $4 \mathrm{Ma})$, implying a recent renewal or acceleration of uplift. Our observations also indicate that during the last 400 $\mathrm{ka}$, the uplift is quite homogeneous all along our study area, with the exception of peninsulas and the area where the Nazca Ridge is subducting. This argues for regional forearc uplift instead of local effects that should show some segmentation along the studied coastline.

These data seem to require a mechanism of uplift (and preceding subsidence) operating at deep crustal or lithospheric levels, such as subduction processes or lithospheric mantle dynamics under the Central Andes. Proposed causes are multiple. It could be the result of a changing Benioff zone dip, as proposed by Folguera et al. (2006) for the southern Andes (36$39^{\circ} \mathrm{S}$ ) and modelled by Guillaume et al. (2009). This would imply a slab steepening during the Pliocene (subsidence) followed by Quaternary slab flattening: this remains to be proved. Otherwise it could be caused by temporal changes in climate-driven trench-fill leading to modifications in plate coupling (Lamb and Davis, 2003). Currently, no data support the hypothesis of a wetter climate during the Pliocene, although a wetter climate would allow for an increase in trench fill and subsidence due to diminished plate coupling.

\section{Conclusion}

Marine morphologies along the central Andes coast reveal that the forearc was uplifted relatively continuously during the late Quaternary, apart from the peninsulas. This uplift is attested by abandoned rasa surfaces found along the coast, and corresponds to a renewal of uplift since at least $400 \mathrm{ka}$ (MIS 11), after Pliocene quiescence or subsidence. For the moment, no cause has been identified for this uplift renewal.

In the peninsulas, a higher level is found, with a proposed age of $\sim 800-1,000 \mathrm{ka}$, with lower certainty. This indicates that peninsulas have been rising for a longer period of time, allowing for a longer glacial-interglacial history to be traced in the geomorphic record. In particular, they highlight that the MIS 11 sea-level highstand is important for coastal morphogenesis, probably due to its long duration (Siddall et al., 2006). 


\section{Acknowledgements}

C. Cavare-Hester has drawn the sketch contained in Figure 2A. We thank French SHOM/INSU relief program ("rocky coast erosion: from observation to modelling", leaded by VR) and the IRD for support. S. Bensmihen is thanked for English corrections. Two anonymous reviewers are warmly thanked for the extensive work they did to improve this manuscript.

\section{Bibliography}

Alvarez-Marron, J., Hetzel, R., Niedennann, S., Menendez, R. and Marquinez, J., 2008. Origin, structure and exposure history of a wave-cut platform more than $1 \mathrm{Ma}$ in age at the coast of northern Spain: A multiple cosmogenic nuclide approach. Geomorphology, 93(3-4): 316-334.

Andersen, M.B. et al., 2008. High-precision U-series measurements of more than 500,000 year old fossil corals. Earth And Planetary Science Letters, 265(1-2): 229-245.

Audin, L., Lacan, P., Tavera, H. and Bondoux, F., 2008. Upper plate deformation and seismic barrier in front of Nazca subduction zone: The Chololo Fault System and active tectonics along the Coastal Cordillera, southern Peru. Tectonophysics, 459(1-4): 174185.

Bradley, W.C. and Griggs, G.B., 1976. Form, genesis, and deformation of some central California wave-cut platforms. Bull Geol. Soc. Am., 87: 433-449.

Bull, W.B., 1985. Correlation of flights of global marine terraces. In: M. Morisawa and J.T. Hack (Editors), Tectonic Geomorphology. The Binghamton Symposia in Geomorphology International Series.

Clift, P.D. and Hartley, A.J., 2007. Slow rates of subduction erosion and coastal underplating along the Andean margin of Chile and Peru. Geology, 35(6): 503-506.

Cueto y Rui Diaz, E., 1930. Nota acerca de las llanuras, rasas y sierras planas de la costa de Asturias. Bol. Real. Soc. Esp. de Hist. Nat.: 241-254.

Darwin, C., 1846. Geological observations on South America. Smith, Elder and Co., London. Delouis, B., Philip, H., Dorbath, L. and Cisternas, A., 1998. Recent crustal deformation in the Antofagasta region (northern Chile) and the subduction process. Geophysical Journal International, 132(2): 302-338.

DeMets, C., Gordon, R.G., Argus, D.F. and Stein, S., 1990. Current Plate Motions. Geoph. J. Int., 101: 425-478.

Domeyko, I., 1848. Mémoire sur le terrrain tertiaire et les lignes d'ancien niveau de l'Océan du sud, aux environs de Coquimbo (Chili). Annales des Mines, 14: 153-162.

Ehlers, T.A. and Poulsen, C.J., 2009. Influence of Andean uplift on climate and paleoaltimetry estimates. Earth and Planetary Science Letters, 281(3-4): 238.

El-Asmar, H., 1997. Quaternary Isotope Stratigraphy and Paleoclimate of Coral Reef Terraces, Gulf of Aqaba, South Sinai, Egypt. Quaternary Science Reviews, 16: 911924.

Espurt, N. et al., 2007. How does the Nazca Ridge subduction influence the modern Amazonian foreland basin? Geology, 35(6): 515-518.

Farías, M., Charrier, R., Comte, D., Martinod, J. and Herail, G., 2005. Late Cenozoic deformation and uplift of the western flank of the Altiplano: Evidence from the depositional, tectonic, and geomorphologic evolution and shallow seismic activity (northern Chile at 19 degrees 30 ' S). Tectonics, 24(4).

Farr, T.G. et al., 2007. The Shuttle Radar Topography Mission. Rev. Geophys., 45: RG2004, doi:10.1029/2005RG000183. 
Folguera, A., Zapata, T. and Ramos, V.A., 2006. Late Cenozoic extension and the evolution of the Neuquén Andes. In: S.M. Kay and V.A. Ramos (Editors), Evolution of an Andean margin: A tectonic and magmatic view from the Andes to the Neuquén Basin (35-39 ${ }^{\circ}$ S lat.). Geological Society of America Special Paper 407, pp. 267-285.

Gansser, A., 1973. Facts and theories on the Andes. Journal of the Geological Society of London, 129: 93-131.

Garcia, M., Gardeweg, M., Clavero, J. and Herail, G., 2004. Hola Arica, Región de Tarapaca, Servicio Nacional de Geología y Mineria.

Gonzalez, G., Cembrano, J., Carrizo, D., Macci, A. and Schneider, H., 2003. The link between forearc tectonics and Pliocene-Quaternary deformation of the Coastal Cordillera, northern Chile. Journal of South American Earth Sciences, 16: 321-342.

Goy, J., Machare, J., Ortlieb, L. and Zazo, C., 1992. Quaternary shorelines in southern Peru: A record of global sea-level fluctuations and tectonic uplift in Chala Bay. Quaternary International, 15-16: 99.

Guillaume, B., Martinod, J. and Espurt, N., 2009. Variations of slab dip and overriding plate tectonics during subduction: Insights from analogue modelling. Tectonophysics, 463(1-4): 167-174.

Hampel, A., 2002. The migration history of the Nazca Ridge along the Peruvian active margin: a re-evaluation. Earth and Planetary Science Letters, 203(2): 665-679.

Hartley, A.J. and Jolley, E.J., 1995. Tectonic Implications Of Late Cenozoic Sedimentation From The Coastal Cordillera Of Northern Chile (22-24-Degrees-S). Journal Of The Geological Society, 152: 51-63.

Hernandez-Pacheco, F., 1950. Las rasas litorales de la costa cantabrica en su segmento asturiano, XVIe Congrès international de géographie, Lisbonne, pp. 29-86.

Hoke, G.D. et al., 2007. Geomorphic evidence for post-10 Ma uplift of the western flank of the central Andes 18 degrees 30'-22 degrees S. Tectonics, 26(5).

Hsu, J.T., Leonard, E.M. and Wehmiller, J.F., 1989. Aminostratigraphy of Peruvian and Chilean Quaternary marine terraces. Quaternary Science Reviews, 8: 255-262.

Huamán, D., 1985. Evolution tectonique Cénozoique et néotectonique du piémont pacifique dans la region d Aréquipa (Andes du Sud du Pérou), Univ. Paris XI, Orsay, France, $220 \mathrm{pp}$ pp.

Keller, E.A. and Pinter, N., 2002. Active tectonics: earthquakes, uplift, and landscape. Prentice Hall, Upper Saddle River, NJ, 362 pp.

Labonne, M. and Hillaire-Marcel, C., 2000. Geochemical gradients within modern and fossil shells of Concholepas concholepas from northern Chile: an insight into U-Th systematics and diagenetic/authigenic isotopic imprints in mollusk shells. Geochimica et Cosmochimica Acta, 64(9): 1523.

Lajoie, K.R., 1986. Coastal Tectonics, Active Tectonics Impact on Society. Nac. Academy Press, Washington D.C.

Lamb, S. and Davis, P., 2003. Cenozoic climate change as a possible cause for the rise of the Andes. Nature, 425(6960): 792-797.

le Roux, J.P., Correa, C.T. and Alayza, F., 2000. Sedimentology of the Rimac-Chillon alluvial fan at Lime, Peru, as related to Plio-Pleistocene sea-level changes, glacial cycles and tectonics. Journal Of South American Earth Sciences, 13(6): 499-510.

Le Roux, J.P. et al., 2005. Neogene-Quaternary coastal and offshore sedimentation in north central Chile: Record of sea-level changes and implications for Andean tectonism. Journal Of South American Earth Sciences, 19(1): 83-98.

Leonard, E.M., Muhs, D.R., Ludwig, K.R. and Wehmiller, J.F., 1994. Coral Uranium-series ages and mollusc amino-acid ratios from uplifted marine terrace deposits, Morro de 

(AMQUA), 13th Biennal Meeting, pp. 223.

Leonard, E.M. and Wehmiller, J.F., 1991. Geochronology of marine terraces at Caleta Michilla, northern Chile; implications for late Pleistocene and Holocene uplift. Revista Geologica De Chile, 18(1): 81-86.

Leonard, E.M. and Wehmiller, J.F., 1992. Low Uplift Rates and Terrace Reoccupation Inferred from Mollusk Aminostratigraphy, Coquimbo Bay Area, Chile. Quaternary Research, 38: 246-259.

Machare, J. and Ortlieb, L., 1992. Plio-Quaternary vertical motions and the subduction of the Nazca Ridge, central coast of Peru. Tectonophysics, 205(1-3): 97.

Marquardt, C., 2005. Déformations néogènes le long de la côte nord du Chili $\left(23^{\circ}-27^{\circ} \mathrm{S}\right)$, avant-arc des Andes centrales, Toulouse III.

Marquardt, C., Lavenu, A., Ortlieb, L., Godoy, E. and Comte, D., 2004. Coastal neotectonics in Southern Central Andes: uplift and deformation of marine terraces in Northern Chile (27 degrees S). Tectonophysics, 394(3-4): 193-219.

Muhs, D.R., 1983. Quaternary Sea Level Events on Northern San Clemente Island, California. Quaternary Research, 20: 322-341.

Ortlieb, L., Ghaleb, B., Hillaire-Marcel, C., Machare, J. and Pichet, P., 1992. Déséquilibres $\mathrm{U} / \mathrm{Th}$, rapports allo/isoleucine et teneurs en 180 des mollusques de dépôts littoraux pléistocénes du sud du Pérou: une base d'appréciation chronostratigraphique. Comptes Rendus De L'Academie Des Sciences Paris, 314: 101-107.

Ortlieb, L., Goy, J.L., Zazo, C., Hillaire-Marcel, C. and Vargas, G., 1995. Late Quaternary Coastal Changes in Northern Chile, Guidebook for a fieldtrip (Antofagasta-Iquique, 23-25 november 1995), Annual Meeting of IGCP Project 367. ORSTOM, Antofagasta, Chile, pp. 176.

Ortlieb, L., Zazo, C., Goy, J.L., Dabrio, C. and Machare, J., 1996a. Pampa del Palo: An anomalous composite marine terrace on the uprising coast of southern Peru. Journal Of South American Earth Sciences, 9(5-6): 367-379.

Ortlieb, L. et al., 1996b. Coastal deformation and sea-level changes in the northern Chile subduction area (23 degrees S) during the last 330 ky. Quaternary Science Reviews, 15(8-9): 819-831.

Ota, Y., Miyauchi, T., Paskoff, R. and Koba, M., 1995. Plioquaternary Marine Terraces And Their Deformation Along The Altos De Talinay, North-Central Chile. Revista Geologica De Chile, 22(1): 89-102.

Paskoff, R., 1970. Recherches géomorphologiques dans le Chili semi-aride. Biscaye Freres, Bordeaux, $420 \mathrm{pp}$.

Paskoff, R., 1977. The Quaternary of Chile: the state of research. Quaternary Research, 8: 231.

Paskoff, R., 1978. Sur l'évolution géomorphologique du grand escarpement du désert chilien. Geogr. Phys. Quat., 32: 351-360.

Paskoff, R. et al., 1995. Field Meeting in the La Serena-Coquimbo Bay Area (Chile), Guidebook for a fieldtrip (Antofagasta-Iquique, 27-28 november 1995), Annual Meeting of IGCP Project 367. ORSTOM, Antofagasta, Chile, pp. 69.

Pedoja, K. et al., 2006a. Plio-Quaternary uplift of the Manta Peninsula and La Plata Island and the subduction of the Carnegie Ridge, central coast of Ecuador. Journal Of South American Earth Sciences, 22(1-2): 1-21.

Pedoja, K. et al., 2006b. Quaternary coastal uplift along the Talara Arc (Ecuador, Northern Peru) from new marine terrace data. Marine Geology, 228(1-4): 73-91.

Pirazzoli, P.A. et al., 1993. A one million-year-long sequence of marine terraces on Sumba Island, Indonesia. Marine Geology, 109: 221-236. 
Quezada, J., Gonzalez, G., Dunai, T., Jensen, A. and Juez-Larre, J., 2007. Pleistocene littoral uplift of northern Chile: Ne-21 age of the upper marine terrace of Caldera-Bahia Inglesa area. Revista Geologica De Chile, 34(1): 81-96.

Radtke, U., 1987. Palaeo sea levels and discrimination of the last and the penultimate interglacial fossiliferous deposits by absolute dating methods and geomorphological investigations illustrated from marine terraces in Chile. Berliner geographische Studien, 25: 313-342.

Radtke, U., 1989. Marine Terrassen und Korallenriffe. Das Probleem der Quartären Meerespiegelschwankungen erlänter an Fallstudien aus Chile, Argentinien und Barbados. Düsseldorfer geographische Schriften, Heft 27: 245.

Regard, V. et al., 2009. Geomorphic evidence for recent uplift of the Fitzcarrald Arch (Peru): a response to the Nazca Ridge subduction. Geomorphology, 107: 107-117.

Saillard, M., 2008. Dynamique du soulèvement côtier Pléistocène des Andes centrales: Etude de l'évolution géomorphologique et datations (10Be) de séquences de terrasses marines (Sud Pérou - Nord Chili), Université de Toulouse, 314 pp.

Saillard, M. et al., 2009. Non-steady long-term uplift rates and Pleistocene marine terrace development along the Andean margin of Chile $\left(31^{\circ} \mathrm{S}\right)$ inferred from $10 \mathrm{Be}$ dating. Earth and Planetary Science Letters, 277(1-2): 50.

Schildgen, T.F. et al., 2009. Quantifying canyon incision and Andean Plateau surface uplift, southwest Peru: A thermochronometer and numerical modeling approach. Journal Of Geophysical Research-Earth Surface, 114.

Schildgen, T.F., Hodges, K.V., Whipple, K.X., Reiners, P.W. and Pringle, M.S., 2007. Uplift of the western margin of the Andean plateau revealed from canyon incision history, southern Peru. Geology, 35(6): 523-526.

Shackleton, N.J., Berger, A. and Peltier, W.R., 1990. An Alternative Astronomical Calibration Of The Lower Pleistocene Timescale Based On Odp Site 677. Transactions Of The Royal Society Of Edinburgh-Earth Sciences, 81: 251-261.

Siddall, M., Chappell, J. and Potter, E.-K., 2006. Eustatic Sea Level During Past Interglacials. In: F. Sirocko, T. Litt, M. Claussen and M.-F. Sanchez-Goni (Editors), The climate of past interglacials. Elsevier, Amsterdam, pp. 75-92.

Siddall, M., Honisch, B., Waelbroeck, C. and Huybers, P., 2010. Changes in deep Pacific temperature during the mid-Pleistocene transition and Quaternary. Quaternary Science Reviews, 29(1-2): 170-181.

Thouret, J.C. et al., 2007. Geochronologic and stratigraphic constraints on canyon incision and Miocene uplift of the Central Andes in Peru. Earth And Planetary Science Letters, 263(3-4): 151-166.

Tobar, A., Salas, R. and Kast, R., 1968. Cuadrangulos Camaraca y Azapa, Provincia de Tarapaca. Carta Geol. Chile, 19 - 20: 13.

Wipf, M., Zeilinger, G., Seward, D. and Schlunegger, F., 2008. Focused subaerial erosion during ridge subduction: impact on the geomorphology in south-central Peru. Terra Nova, 20(1): 1-10.

Wörner, G., Hammerschmidt, K., Henjes-Kunst, F., Lezaun, J. and Wilke, H., 2000. Geochronology (Ar-40/Ar-39, K-Ar and He-exposure ages) of Cenozoic magmatic rocks from Northern Chile (18-22 degrees $\mathrm{S}$ ): implications for magmatism and tectonic evolution of the central Andes. Revista Geologica De Chile, 27(2): 205-240.

Yañez, G., Cembrano, J., Pardo, M., Ranero, C. and Selles, D., 2002. The Challenger-Juan Fernandez-Maipo major tectonic transition of the Nazca-Andean subduction system at 33-34 degrees S: geodynamic evidence and implications. Journal of South American Earth Sciences, 15(1): 23-38. 
Yañez, G.A., Ranero, C.R., von Huene, R. and Diaz, J., 2001. Magnetic anomaly interpretation across the southern central Andes (32 degrees-34 degrees S): The role of the Juan Fernandez Ridge in the late Tertiary evolution of the margin. Journal Of Geophysical Research-Solid Earth, 106(B4): 6325-6345.

\section{Tables}

Table 1.

Extrapolation of terrace ages to cliff foot ages. Data are a compilation taken from single works (and papers); all the data are presented in the additional Table. Each datum is assigned to a Marine Isotopic Stage (MIS); accuracy of this assignment is evaluated: 1: age is that of cliff foot (bold-faced extrapolated ages); 2: good, assignment must be to the correct MIS substage; 3 : medium, the numerical age corresponds to a different substage to the one the data are assigned to; 4: lower: the uncertainty is of the order of one interglacial; 5: low, the uncertainty is of the order of a couple of hundred thousand years. The ancient sea level is taken from relevant studies (Andersen et al., 2008; Shackleton et al., 1990; Siddall et al., 2006). Data references are: 1-Saillard (2008); 2- Radtke (1987; 1989) ; 3-Leonard and Wehmiller (1992) ; 4-Quezada et al. (2007); 5-Marquardt et al. (2004); 6-Leonard et al. (1994); 7- GEOTOP, in Ortlieb et al. (1995); 8-Gonzalez, in Marquardt (2005); 9-Ortlieb et al. (1996b); 10-Leonard and Wehmiller (1991); 11-Labonne and Hillaire-Marcel (2000); 12Ortlieb et al. (1992); 13-Ortlieb et al. (1996a).

\section{Table ADDITIONAL MAT 1.}

Terrace age data from literature. The column sample/MIS indicate if the age is the one of the sample(s) analyzed (sample) or if it was adjusted to an interglacial highstand (MIS); when many samples are available for any specific locality, they are numbered in order to follow dates performed on one sample (frequent when ESR, U-Th or A/I are used) or dates coming from different sample associations. 'inf' in '+' uncertainty indicates minimum values. When many dates are available for one single place, an average value is calculated by weighting with the inverse of uncertainty (the minimum values are not taken into account). Reference to relevant papers are indicated; nevertheless, most of the data earlier than 1995 are reproduced in Ortlieb et al. (1995) and Paskoff et al. (1995). 


\begin{tabular}{|c|c|c|c|c|c|c|c|c|c|c|c|c|c|c|c|c|c|c|c|c|c|c|}
\hline Site Name & $\begin{array}{l}\text { latitude } \\
\text { (degrees } \\
\text { N) } \\
\end{array}$ & Age (kyr) & & MIS & accuracy & Technique & Dated material & $\begin{array}{l}\text { Terrace } \\
\text { shoreline } \\
\text { angle or } \\
\text { sample } \\
\text { elevation (m) }\end{array}$ & \pm & Reference & $\begin{array}{l}\text { ancient } \\
\text { sea level } \\
\text { (m) }\end{array}$ & \pm & $\begin{array}{l}\text { uplift } \\
\text { rate } \\
(\mathrm{m} / \mathrm{m} / \mathrm{r})\end{array}$ & & $\begin{array}{l}\text { cliff foot } \\
\text { elevation } \\
\text { (m) }\end{array}$ & Main & $\begin{array}{l}\text { extrapolated } \\
\text { age (kyr) }\end{array}$ & \pm & $\begin{array}{l}\text { lifff foot } \\
\text { elevation } \\
\text { (m) }\end{array}$ & Uppe & $\begin{array}{l}\text { extrapolated } \\
\text { age (kyr) }\end{array}$ & $\begin{array}{l}\text { ed } \\
\pm\end{array}$ \\
\hline altos de Talinay & -30.5 & 122 & 75 & $5 e$ & 2 & 10Be & \multirow{4}{*}{$\begin{array}{l}\text { Surface } \\
\text { exposure age, } \\
\text { no erosion }\end{array}$} & 25 & 3 & 1 & 3 & 3 & 0.18 & 0.05 & 170 & 20 & 943 & 285 & 425 & 515 & 2357 & $57 \quad 662$ \\
\hline altos de Talinay & -30.5 & 225 & 127 & $7 \mathrm{e}$ & 2 & 10Be & & 55 & 5 & 1 & -10 & 5 & 0.29 & 0.05 & 170 & 20 & 588 & 118 & 425 & 515 & 1471 & $71 \quad 245$ \\
\hline altos de Talinay & -30.5 & 321 & 7 & $9 \mathrm{c}$ & $1 ; 2$ & 10Be & & 170 & 20 & 1 & -2.5 & 5.5 & 0.54 & 0.08 & 170 & 20 & 321 & 7 & 425 & 515 & 791 & $91 \quad 121$ \\
\hline altos de Talinay & -30.5 & 690 & 10 & 17 & $3 ; 1$ & $10 \mathrm{Be}$ & & 425 & 15 & 1 & -15 & 15 & 0.64 & 0.04 & 170 & 20 & 267 & 36 & 425 & $5 \quad 15$ & & $90 \quad 10$ \\
\hline Tongoy & -30.25 & 122 & 75 & $5 e$ & 3 & $\mathrm{U} / \mathrm{Th}$ & \multirow{12}{*}{$\begin{array}{l}\text { Marine shells in } \\
\text { terrace material }\end{array}$} & 14 & 2 & 1 & 3 & 3 & 0.09 & 0.04 & & & & & 155 & 515 & 1719 & 19805 \\
\hline Tongoy & -30.25 & 404 & 71 & 11 & 5 & $\mathrm{U} / \mathrm{Th}$ & & 48 & 2 & 1 & 8 & 10 & 0.1 & 0.03 & & & & & 155 & $5 \quad 15$ & 1305 & $05 \quad 412$ \\
\hline Guanaqueros & -30.2 & 100 & 75 & $5 c$ & 3 & U/Th \& ESR & & 18 & 2 & 2 & -15 & 10 & 0.33 & 0.12 & 130 & 10 & 394 & 149 & 155 & 515 & & $\begin{array}{ll}70 & 180\end{array}$ \\
\hline Herradura & -30 & 122 & 75 & $5 e$ & 2 & U/Th \& ESR & & 17.5 & 2.5 & 2 & 3 & 3 & 0.12 & 0.05 & 130 & 10 & 1094 & 428 & 165 & 530 & 1388 & $88 \quad 589$ \\
\hline Herradura & -30 & 122 & 75 & $5 e$ & 3 & U/Th \& ESR & & 22 & 2.5 & 3 & 3 & 3 & 0.16 & 0.05 & 130 & 10 & 835 & 255 & 165 & 530 & 1059 & $\begin{array}{ll}59 & 367\end{array}$ \\
\hline Herradura & -30 & 225 & 127 & $7 e$ & 4 & U/Th \& ESR & & 37.5 & 2.5 & 2 & -10 & 5 & 0.21 & 0.04 & 130 & 10 & 616 & 113 & 165 & 530 & 782 & 82193 \\
\hline Herradura & -30 & 404 & 7 & 11 & 4 & $\mathrm{~A} / \mathrm{l}$ & & 41 & 5 & 3 & 8 & 10 & 0.08 & 0.04 & 130 & 10 & 1592 & 734 & 165 & 530 & 2020 & 20990 \\
\hline South Coquimbo Bay & -30 & 321 & 7 & $9 \mathrm{c}$ & 4 & $\mathrm{~A} / \mathrm{l}$ & & 28 & 5 & 3 & -2.5 & 5.5 & 0.1 & 0.03 & 130 & 10 & 1368 & 484 & 165 & 530 & 1737 & $37 \quad 677$ \\
\hline North Coquimbo Bay & -29.9 & 122 & 75 & $5 e$ & 3 & $\mathrm{~A} / \mathrm{l}$ & & 25 & 5 & 3 & 3 & 3 & 0.18 & 0.07 & 130 & 10 & 721 & 271 & 170 & 15 & 943 & $43 \quad 357$ \\
\hline North Coquimbo Bay & -29.9 & 404 & 71 & 11 & 4 & $\mathrm{~A} / \mathrm{I}$ & & 58 & 5 & 3 & 8 & 10 & 0.12 & 0.04 & 130 & 10 & 1050 & 326 & 170 & 15 & 1374 & $74 \quad 430$ \\
\hline Punta teatinos & -29.8 & 122 & 75 & $5 e$ & 2 & U/Th \& ESR & & 30 & 3 & 2 & 3 & 3 & 0.22 & 0.05 & 130 & 10 & 587 & 142 & 170 & 15 & & 68189 \\
\hline Punta teatinos & -29.8 & 225 & 127 & $7 e$ & 2 & $\mathrm{U} / \mathrm{Th} \& \mathrm{ESR}$ & & 62 & 3 & 2 & -10 & 5 & 0.32 & 0.04 & 130 & 10 & 406 & 59 & 170 & 015 & & $31 \quad 81$ \\
\hline Quebrada Honda & -29.6 & 122 & 75 & $5 e$ & 3 & U/Th \& ESR & $\begin{array}{l}\text { Marine shells in } \\
\text { terrace material }\end{array}$ & 24 & 3 & 2 & 3 & 3 & 0.17 & 0.05 & 80 & 15 & 465 & 161 & 180 & 035 & & $46 \quad 366$ \\
\hline Huasco & -28.3 & 122 & 75 & $5 e$ & 3 & U/Th \& ESR & $\begin{array}{l}\text { Marine shells in } \\
\text { terrace material }\end{array}$ & 30 & 5 & 2 & 3 & 3 & 0.22 & 0.07 & 148 & 10 & 669 & 207 & & & & \\
\hline Puerto Viejo & -27.33 & 100 & 75 & $5 c$ & 3 & U/Th \& ESR & \multirow{2}{*}{$\begin{array}{l}\text { Marine shells in } \\
\text { terrace material }\end{array}$} & 30 & 3 & 2 & -15 & 10 & 0.45 & 0.13 & 130 & 10 & 289 & 89 & 260 & 10 & & $67 \quad 260$ \\
\hline Puerto Viejo & -27.33 & 122 & 75 & $5 e$ & 3 & U/Th \& ESR & & 55 & 5 & 2 & 3 & 3 & 0.43 & 0.07 & 130 & 10 & 305 & 55 & 260 & 10 & & $77 \quad 97$ \\
\hline Caldera & -27.06 & 100 & 75 & $5 c$ & 2 & U/Th & \multirow{2}{*}{$\begin{array}{l}\text { Marine shells in } \\
\text { terrace material }\end{array}$} & 23 & 2 & 2 & -15 & 10 & 0.38 & 0.12 & 120 & 10 & 316 & 105 & 250 & 30 & 1087 & $87 \quad 375$ \\
\hline Bahia Inglesa & -27.12 & 100 & 75 & $5 c$ & 2 & U/Th \& ESR & & 15 & 2 & 2 & -15 & 10 & 0.3 & 0.12 & 130 & 10 & 433 & 179 & 260 & 10 & 1733 & $33 \quad 707$ \\
\hline Bahia Inglesa & -27.12 & 122 & 75 & $5 e$ & 2 & U/Th \& ESR & Surface & 36 & 5 & 2 & 3 & 3 & 0.27 & 0.07 & 130 & 10 & 481 & 125 & 260 & 10 & & $81 \quad 222$ \\
\hline Caldera & -27.15 & 860 & 152 & 21 & $3 ; 1$ & $21 \mathrm{Ne}$ & no erosion & 224 & 0 & 4 & 0 & 20 & 0.26 & 0.02 & 120 & 10 & 461 & 39 & 224 & 6 & & $\begin{array}{ll}60 & 15\end{array}$ \\
\hline Caldera & -27.12 & 404 & 7 & 11 & $1 ; 4$ & Faunal assemblage & $\begin{array}{l}\text { Terrace marine } \\
\text { sediments }\end{array}$ & 162 & 10 & 5 & 8 & 10 & 0.38 & 0.05 & 120 & 10 & 315 & 49 & 250 & 30 & & $56 \quad 117$ \\
\hline Morro de Copiapo & -27.1 & 500 & 10 & 13 & $1 ; 4$ & $\mathrm{U} / \mathrm{Th}$ & $\begin{array}{l}\text { Marine shells in } \\
\text { terrace material }\end{array}$ & 130 & 10 & 6 & 0 & 20 & 0.26 & 0.06 & 120 & 10 & 462 & 114 & 250 & 30 & & $62 \quad 251$ \\
\hline Bahia Inglesa & -27.06 & 404 & 7 & 11 & $1 ; 4$ & Faunal assemblage & $\begin{array}{l}\text { Terrace marine } \\
\text { sediments }\end{array}$ & 139 & 10 & 5 & 8 & 10 & 0.32 & 0.05 & 120 & 10 & 370 & 65 & 250 & 30 & & $71 \quad 150$ \\
\hline Obispito & -26.45 & 122 & 75 & $5 e$ & 3 & U/Th \& ESR & $\begin{array}{l}\text { Marine shells in } \\
\text { terrace material }\end{array}$ & 35 & 8 & 2 & 3 & 3 & 0.26 & 0.09 & 95 & 15 & 362 & 139 & 240 & 20 & & 15328 \\
\hline Pan de Azucar & -26.15 & 122 & 75 & $5 e$ & 3 & U/Th \& ESR & $\begin{array}{l}\text { Marine shells in } \\
\text { terrace material }\end{array}$ & 33 & 3 & 2 & 3 & 3 & 0.25 & 0.05 & 100 & 20 & 407 & 117 & & & & \\
\hline Cifuncho & -25.65 & 122 & 75 & $5 e$ & 3 & U/Th \& ESR & $\begin{array}{l}\text { Marine shells in } \\
\text { terrace material }\end{array}$ & 34 & 2 & 2 & 3 & 3 & 0.25 & 0.04 & 100 & 20 & 394 & 104 & & & & \\
\hline Coloso & -23.75 & 122 & 75 & $5 e$ & 2 & U/Th \& ESR & \multirow{2}{*}{$\begin{array}{l}\text { Marine shells in } \\
\text { terrace material }\end{array}$} & 18 & 2 & 2 & 3 & 3 & 0.12 & 0.04 & 110 & 20 & 895 & 344 & 320 & 10 & 2603 & $03 \quad 884$ \\
\hline Coloso & -23.75 & 225 & 12 & $7 \mathrm{e}$ & 3 & U/Th \& ESR & & 32 & 2 & 2 & -10 & 5 & 0.19 & 0.03 & 110 & 20 & 589 & 149 & 320 & 010 & 1714 & $14 \quad 305$ \\
\hline Abtao & -23.45 & 225 & 127 & $7 e$ & 3 & ESR & \multirow{2}{*}{$\begin{array}{l}\text { Marine shells in } \\
\text { terrace material }\end{array}$} & 20 & 5 & 2 & -10 & 5 & 0.13 & 0.05 & 90 & 10 & 675 & 240 & 150 & 30 & 1688 & $88 \quad 662$ \\
\hline Abtao & -23.45 & 225 & 127 & $7 e$ & 2 & U/Th \& A/l & & 23 & 5 & 7 & -10 & 5 & 0.15 & 0.05 & 90 & 10 & 614 & 201 & 150 & 30 & 1467 & $67 \quad 538$ \\
\hline Abtao & -23.45 & 321 & 7 & $9 \mathrm{c}$ & $1 ; 3$ & U/Th \& A/l & $\begin{array}{l}\text { Surface } \\
\text { exposure age, }\end{array}$ & 90 & 10 & 7 & -2.5 & 5.5 & 0.29 & 0.05 & 90 & 10 & 321 & 7 & 150 & 30 & & 35140 \\
\hline Morro Mejillones & -23.1 & 404 & 71 & 11 & $1 ; 3$ & $21 \mathrm{Ne}$ & no erosion & 250 & 20 & 8 & 8 & 10 & 0.6 & 0.07 & 250 & 20 & 404 & 7 & 455 & 520 & & $\begin{array}{ll}35 & 98\end{array}$ \\
\hline Mejillones north & -23.05 & 122 & 75 & $5 e$ & 2 & U/Th \& ESR & \multirow{2}{*}{$\begin{array}{l}\text { Marine shells in } \\
\text { terrace material }\end{array}$} & 14.5 & 1 & 2 & 3 & 3 & 0.09 & 0.03 & 130 & 30 & 1379 & 581 & 200 & 30 & 2122 & 22813 \\
\hline Mejillones north & -23.05 & 225 & 127 & $7 e$ & 4 & U/Th \& ESR & & 31 & 1 & 2 & -10 & 5 & 0.18 & 0.03 & 130 & 30 & 713 & 199 & 200 & 30 & 1098 & 982 \\
\hline
\end{tabular}




\begin{tabular}{|c|c|c|c|c|c|c|c|c|c|c|c|c|c|c|c|c|c|c|c|c|}
\hline Mejillones north & -23.05 & 321 & 7 & $9 c$ & 5 & U/Th \& ESR & & 45 & 10 & 2 & -2.5 & & 0.15 & 0.05 & $130 \quad 30$ & $879 \quad 352$ & 200 & & 1352 & 486 \\
\hline Chacaya & -23 & 122 & 7 & $5 e$ & 3 & $\mathrm{~A} / \mathrm{l}$ & \multirow{9}{*}{$\begin{array}{l}\text { Marine shells in } \\
\text { terrace material }\end{array}$} & 33 & 3 & 9 & 3 & 3 & 0.25 & 0.05 & 11010 & $\begin{array}{ll}447 & 102\end{array}$ & 200 & 30 & 813 & 209 \\
\hline Chacaya & -23 & 225 & 12 & $7 e$ & 2 & U/Th & & 90 & 10 & 9 & -10 & 5 & 0.44 & 0.07 & 11010 & $248 \quad 45$ & 200 & 30 & 450 & 98 \\
\hline Chacaya & -23 & 321 & 7 & $9 c$ & 4 & A/l & & 90 & 10 & 9 & -2.5 & 5.5 & 0.29 & 0.05 & 11010 & $\begin{array}{ll}382 & 73\end{array}$ & 200 & 30 & 694 & 157 \\
\hline Hornitos & -22.9 & 122 & 7 & $5 e$ & 3 & U/Th \& ESR & & 36 & 2 & 2 & 3 & 3 & 0.27 & 0.04 & 11010 & $407 \quad 76$ & 170 & 20 & 628 & 126 \\
\hline Hornitos & -22.9 & 100 & 7 & $5 c$ & 3 & $\mathrm{~A} / \mathrm{l}$ & & 33 & 3 & 9 & -15 & 10 & 0.48 & 0.13 & 11010 & $229 \quad 67$ & 170 & 20 & 354 & 107 \\
\hline Hornitos & -22.9 & 122 & 7 & $5 e$ & 3 & $\mathrm{~A} / \mathrm{l}$ & & 33 & 3 & 9 & 3 & 3 & 0.25 & 0.05 & 11010 & $\begin{array}{ll}447 & 102\end{array}$ & 170 & 20 & 691 & 165 \\
\hline Hornitos & -22.9 & 122 & 7 & $5 e$ & 3 & $\mathrm{U} / \mathrm{Th}$ & & 33 & 3 & 9 & 3 & 3 & 0.25 & 0.05 & 11010 & $\begin{array}{ll}447 & 102\end{array}$ & 170 & 20 & 691 & 165 \\
\hline Hornitos & -22.9 & 225 & 12 & $7 \mathrm{e}$ & 3 & A/l & & 55 & 8 & 9 & -10 & 5 & 0.29 & 0.06 & 11010 & $381 \quad 86$ & 170 & 20 & 588 & 140 \\
\hline Hornitos & -22.9 & 321 & 7 & $9 c$ & 3 & $\mathrm{~A} / \mathrm{l}$ & & 80 & 5 & 9 & -2.5 & 5.5 & 0.26 & 0.03 & $110 \quad 10$ & $428 \quad 68$ & 170 & 20 & 661 & 116 \\
\hline Michilla & -22.7 & 122 & 7 & $5 e$ & 3 & U/th & \multirow{2}{*}{$\begin{array}{l}\text { Marine shells in } \\
\text { terrace material }\end{array}$} & 25 & 10 & 7 & 3 & 3 & 0.18 & 0.11 & 13520 & $749 \quad 458$ & & & & \\
\hline Michilla & -22.7 & 122 & 7 & $5 e$ & 3 & U/h & & 50 & 10 & 11 & 3 & 3 & 0.39 & 0.11 & $135 \quad 20$ & $350 \quad 112$ & & & & \\
\hline Iquique & -20.4 & 122 & 7 & $5 e$ & 2 & U/Th \& ESR & $\begin{array}{l}\text { Marine shells in } \\
\text { terrace material }\end{array}$ & 22 & 2 & 2 & 3 & 3 & 0.16 & 0.04 & $100 \quad 15$ & $642 \quad 198$ & & & & \\
\hline 110 & -17.58 & 321 & 7 & $9 \mathrm{c}$ & $1 ; 3$ & $10 \mathrm{Be}$ & $\begin{array}{l}\text { Surface } \\
\text { exposure age, } \\
\text { no erosion }\end{array}$ & 80 & & 1 & -2.5 & 5.5 & 0.26 & 0.02 & $80 \quad 15$ & 321 & 250 & 30 & 1003 & 122 \\
\hline Ilo & -17.6 & 85 & 7 & $5 a$ & 3 & $\mathrm{U} / \mathrm{th}$ & \multirow{4}{*}{$\begin{array}{l}\text { Marine shells in } \\
\text { terrace material }\end{array}$} & 10 & 3 & 12 & -15 & 10 & 0.29 & 0.15 & $80 \quad 15$ & $272 \quad 152$ & 250 & 30 & 850 & 459 \\
\hline Ilo & -17.7 & 122 & 7 & $5 e$ & 3 & U/th & & 20 & 5 & 12 & 3 & 3 & 0.14 & 0.07 & $80 \quad 15$ & $574 \quad 293$ & 250 & 30 & 1794 & 877 \\
\hline Ilo & -17.7 & 225 & 12 & $7 \mathrm{e}$ & 4 & U/th & & 25 & 5 & 12 & -10 & 5 & 0.16 & 0.05 & $80 \quad 15$ & 514178 & 250 & 30 & 1607 & 505 \\
\hline Ilo & -17.6 & 85 & 7 & $5 a$ & 3 & $\mathrm{~A} / \mathrm{l}$ & & 10 & 3 & 13 & -15 & 10 & 0.29 & 0.15 & $80 \quad 15$ & 272152 & 250 & 30 & 850 & 459 \\
\hline Chala & -15.85 & 122 & 7 & $5 e$ & 5 & 10Be and correlation & \multirow{5}{*}{$\begin{array}{l}\text { Surface } \\
\text { exposure age, } \\
\text { no erosion }\end{array}$} & 60 & 3 & 1 & 3 & 3 & 0.47 & 0.06 & & & 300 & 30 & 610 & 70 \\
\hline Chala & -15.85 & 225 & 12 & $7 e$ & 5 & 10Be and correlation & & 94 & 3 & 1 & -10 & 5 & 0.46 & 0.04 & & & 300 & 30 & 718 & 81 \\
\hline Chala & -15.85 & 321 & 7 & $9 \mathrm{c}$ & 5 & 10Be and correlation & & 154 & 3 & 1 & -2.5 & 5.5 & 0.49 & 0.03 & & & 300 & 30 & 625 & 64 \\
\hline Tanaka & -15.74 & 225 & 12 & $7 \mathrm{e}$ & 3 & $10 \mathrm{Be}$ & & 90 & 10 & 1 & -10 & 5 & 0.44 & 0.07 & & & 300 & 20 & 750 & 64 \\
\hline Chaviña & -15.6 & 321 & 7 & $9 \mathrm{c}$ & 4 & $10 \mathrm{Be}$ & & 150 & 10 & 1 & -2.5 & 5.5 & 0.48 & 0.05 & & & 300 & 20 & 642 & 45 \\
\hline
\end{tabular}

